\title{
Economics for the Common Good
}

JEAN TIROLE (translated by Steven Rendall)

Princeton University Press, Princeton and Oxford, 2017, pp. 576

Book review by PREDRAG BEJAKOVIĆ*

https://doi.org/10.3326/pse.42.2.12

\footnotetext{
* Received: April 4, 2018

Accepted: April 9, 2018

Predrag BEJAKOVIĆ, Ph.D.

Institute of Public Finance, Smičiklasova 21, 10000 Zagreb, Croatia e-mail: predrag@ijf.hr ORCiD: 0000-0002-4164-8220
} 
Economists are often deemed incapable of and uninterested in lessening the most important human problems, such as poverty and inequality. They are blamed for neglecting the issues of morality and for not predicting serious economic crises and financial turmoil. They mostly provide contradictory opinions, while some burden their readers with incomprehensible mathematical formulas and econometric calculations. In his recently published "Economics for the Common Good," Jean Tirole, a French economist and Nobel prize-winner, chairman of the Toulouse School of Economics and the Institute for Advanced Study in Toulouse, tries to defend and protect economists' reputation. His transformation from academic economist to public intellectual motivated him to analyse the role economists and their discipline play in society.

In the Introduction as well in the further text, Tirole admits that some of these criticisms are justified. Leading economists are more willing to create knowledge than to explain to and disseminate it among the broader public. Although mathematical formulas and models are needed because they enable clarity and rigour, they could well disregard the questions asked and be wrongly taken as the goal of the studies rather than as necessary scientific tools. Furthermore, quite often, what the public expects from economists is unrealistic. It is unfair to accuse economists for failing to see and predict events concerning which even the most competent financial supervisors have only limited understanding and knowledge. Crises in most cases cannot be forecast, while it is completely impossible to foresee the future relations between states.

Tirole describes economists as ill-trained and inadequately equipped to deal with the murky reality of everyday politics. Tirole warns possible future stars of TV discussions and articles in popular newspapers that academic economists will be soon put into political boxes, and their statements will be praised or criticised according to the political prejudices and preferences of the observers and readers. Briefly, Tirole is the economists' guardian, but not their saviour.

Apart from the Introduction and the short Epilogue, the book consists of five parts divided in seventeen chapters. In the Introduction, Tirole writes on institutions and sends the most important but often forgotten message of his book: there is no conflict between the state regulation and the market. The state and the market are complementary, not mutually exclusive. The market needs regulation, the state needs competition and incentives (page 10). To be competitive, a market economy requires an efficient state to correct its failures, although sometimes the state does not work for the achievement of the common good. Furthermore, a market economy is not an end in itself, but it is an instrument for the alignment of the private interests of individuals, social groups and nations with the common interest.

In Part I, Economics and society, Tirole dedicates much of his attention to explanations of the role of economics. As a social activity, it should elucidate complex phenomena, help in distinguishing the differences between intended and final 
realised goals of the various public policies and aid in achieving the economic efficiency and financial sustainability of measures related to the public good. Tirole stresses that despite the many pitfalls (primarily insufficient information) and limited number of safeguards, economists should be capable of understanding and explaining the issues of morality. The best response to the claims of moral superiority is not necessarily another moral claim because opposing one's morality to somebody else's leads to confrontation, making problems impossible to resolve (page 35). It is much better to begin with the question: "Who is the victim?" and "Can the infringement of the other be justified?" Tirole explains that having in mind the final outcome, the instinctive moral repugnance to the trade in human organs or blood should not be the reason for the cancelling of such a market. Trade in human organs can increase the supply of donated kidneys and thus save lives.

In Part II, The economist's profession, Tirole analyses various old and new challenges ranging from environmental protection and carbon taxes to industrial policy, from market competition to artificial intelligence and digital economy. He presents two basic rules of personal ethics for economists in their search for the overt and hidden rules of individual and group behaviour: (a) discuss ideas, never persons, and (b) never state anything that you are not ready to defend before your peers (page 76). In the further text, he elucidates the importance of debates and peer-reviews by anonymous referees in journals and although the academic community agrees that questioning theory is essential, criticism is only truly useful if it is constructive (page 87). Economists should behave like policy inspectors searching out with scientific methods the possible abuses of market power in the hope that, in that way, the efficiency of the provision of public good can be enhanced. In such activities, economists have much to learn from other disciplines, and in turn their work can open new lines of research into individual behaviour and social phenomena (page 123).

The institutions of state and market forms are the subject of the third theme, where Tirole situates these institutions in their economic environment. In their activities, public policy decision makers should propose and implement measures according to the Rawls principle that they should be "behind the veil of ignorance". Lawmakers should not know anything about the future, whether any one person, including the policymakers themselves, will benefit or lose from a particular decision. The idea is to incentivize citizens to create wealth for society, but also to provide the preconditions for them to have a relatively decent life even if they are among the most unfortunate. For achieving such a demanding and complex task, an independent authority should be trusted with the general mandate within which it can evaluate options and find technical solutions, a mandate that guarantees coherence in that authority's policies and its independence with regards to pressure groups (page 164). However, Tirole is fully aware that this is only an ideal situation because the independent authorities (the governments) for various reasons are never fully independent. Although the implementation of reforms is a task with questionable results, the positive examples of Germany, the Netherlands 
and the Scandinavian countries in changing their social welfare systems and labour markets clearly show that adequate preparation, optimal time scale and packaging together of various measures can achieve results that are better than expected.

To demonstrate how economics can be useful in the realisation of the common good, Part IV deals with the great macroeconomic challenges of everyday lives and the future of humanity. They include climate change and global warming, problems of the labour market, primarily of long-term unemployment, the problems of Europe at the crossroads, finance and the euro crisis. Fully aware of the danger of the degradation of the human environment, he supports tradable emissions permits and carbon taxes as an efficient means for the prevention of pollution, but reminds us also of different types of "command and control" and supports renewable energy resources approaches, which are sometimes too expensive and not particularly efficient. Such measures often lead to a lack of consistency that substantially increases the costs of reducing emissions (page 206). Germany, for example, spent a huge amount of resources on first generation solar panels regardless of the fact that the country does not have a lot of sunshine. Results comparable to those produced by reduction of $\mathrm{CO}_{2}$ emissions can be achieved with other methods with significantly lower costs. In other words, emissions could have been reduced for the same costs, by one hundred tons rather than one ton. Particularly interesting is a part dedicated to the labour market, where France is characterised by strict and complex labour law regarding dismissal, obsolete institutions and strong trade unions that resist changes. All these factors lead to the polarisation of the labour market into permanently well-off insiders employed on permanent labour contracts and unemployed outsiders that can find only temporary or short-term badly paid jobs. This polarisation is a dirty trick played on employees in general, and especially on the young (page 239).

The final, fifth, section of the book turns to the importance and impact of the digital revolution, innovation, and the proper equilibrium between the free market and regulation. Tirole applies his macroeconomic insight to microeconomic questions like digital platforms and their influence on employment, intellectual property, competition laws and policy and finally, the regulation of network industries. Tirole correctly underlines the importance of new technology explaining that digitalisation has an impact on intellectual property rights, competition law, labour law, taxation and regulation in general. The digital economy is bringing extraordinary technological progress that is giving us better health, as well as more time and purchasing power, but it also creates dangers we cannot ignore (page 378). In the economic analysis and clarification of rules in these areas, he uses the principal-agent approach, applies asymmetric information and underlines the role and significance of incentives. Writing about digitisation in health care, he reminds us that there are huge opportunities in the collection and analysis of very large data sets. This technology enables more precise and less costly diagnoses and may help us to ensure equal access of the population to health care. Equal access is now under pressure from the combination of higher treatment costs and weak 
possibilities of public finance to cover them. Finally, he believes that the right question is not whether due to artificial intelligence and digitisation there will be employment possibilities for people, but whether there will be enough jobs paying decent wages. Without doubt, in comparison to knowledge regarding the economic aspects of the digital technology available hitherto from other economists, Tirole takes a huge step forward in our understanding of the digital economy and society.

Providing an abundant explanation of how economics can benefit everyone, Tirole in Economics for the Common Good defines a new agenda for the role and impact of economists and economics in economy and society. His ability to explain complicated themes clearly and understandably is unfortunately a very rare skill among economists. The book is non-technical and without complicated mathematical formulas, aimed at the general and not particularly knowledgeable reader, and is full of examples from daily life. It should perhaps be required reading for any economist that wants to understand many issues and to learn how to write comprehensibly in a field that is more art than science, because in real life it is very difficult or impossible to collect all the data needed to assess precisely the effects predicted by theory. 